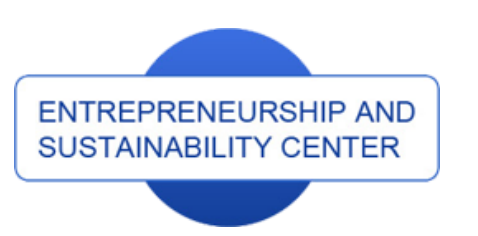

Publisher

http://jssidoi.org/esc/home

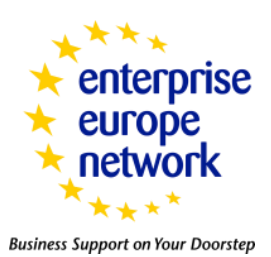

CASPA

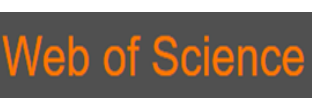

1) Clarivate

\title{
EXTERNAL ASSURANCE ON SUSTAINABILITY REPORT DISCLOSURE AND FIRM VALUE: EVIDENCE FROM INDONESIA AND MALAYSIA*
}

\author{
Iman Harymawan*1, Mohammad Nasih², Atila Salsabilla ${ }^{3}$, Fajar Kristanto Gautama Putra ${ }^{4}$ \\ 1,2,3,4 Universitas Airlangga, Airlangga No. 4-6, Surabaya, 60286, Indonesia \\ E-mails: ${ }^{1}$ harymawan.iman@feb.unair.ac.id (Corresponding author); ${ }^{2}$ mohnasih@feb.unair.ac.id; ${ }^{3}$ \\ atilasalsabillaaa@gmail.com; ${ }^{4}$ fajar.kristanto@akuntanindonesia.or.id
}

Received 15 June 2019; accepted 15 January 2020; published 30 March 2020

\begin{abstract}
We analyze the content of assurance statements on sustainability reports to examine the extent of external assurance on sustainability report disclosure in Indonesian and Malaysian listed companies and identify their impact on firm value. This research is conducted using 84 samples of listed companies from all industries, except the financial industry, for the period 2010-2016. Ordinary least square (OLS) regression is used to test the research hypothesis. The results show a significant positive effect of external assurance on sustainability report disclosure to a firm value measured by Tobins'Q. Besides, we also found that companies in Indonesia have higher disclosure in terms of external assurance for sustainability reports compared to Malaysia. This study adds new evidence to the literature on sustainability assurance in emerging countries.
\end{abstract}

Keywords: sustainability report; external assurance; firm value; emerging countries

Reference to this paper should be made as follows: Harymawan, I., Nasih, M., Salsabilla, A., Putra, F.K.G. 2020. External assurance on sustainability report disclosure and firm value: evidence from Indonesia and Malaysia. Entrepreneurship and Sustainability Issues, 7(3), 1500-1512. https://doi.org/10.9770/jesi.2020.7.3(5)

JEL Classifications: Q560

\section{Introduction}

Presently, corporations are facing increasing pressures to be more accountable, transparent, and to disclose a wide variety of information, including information on sustainability. As part of supporting Sustainable Development Goals (SDGs) number 8 which relates to "Decent Work and Economic Growth", companies should additionally make contributions and adopt sustainable activities. To legalise the implementation of company sustainability, national governments publish the requirements and policies concerning sustainable development, including the

\footnotetext{
* This research has received funding from the Tahir World Class Professorship
} 


\section{ENTREPRENEURSHIP AND SUSTAINABILITY ISSUES}

ISSN 2345-0282 (online) http://jssidoi.org/jesi/ 2019 Volume 7 Number 2 (December) http://doi.org/10.9770/jesi.2019.7.2(..)

Indonesian government which has several regulations, one of which is Article 74 of Law No. 40 of 2007 which relates to managing social and environmental responsibility in terms of the restriction of company liability. Meanwhile, in Malaysia, concerns on the environment have been voiced by the government, and companies are encouraged to provide information on the impact of their economic activities on the environment in their annual reports. ACCA Malaysia has played a significant role in the progress in reporting on sustainability. In 1999, ACCA Malaysia announced that there were 25 participants in the Environmental Reporting Awards (MERA). In 2003, the number had escalated to 60 participants. The event has become a growing success. In 2005, ACCA Malaysia presented the reporting standards for The Malaysian Environmental and Social Reporting Award (MESRA). MESRA was established through the reworking of various reputable guidelines for reporting, for instance the GRI (Sawani et al. 2010). It is not only national governments that require corporations to be socially and environmentally responsible but also a range of fundamental stakeholders including non-governmental organisations, investors and consumers (Gardiner et al. 2003).

As far back as two decades ago, companies began to pay a greater amount of attention to their attempts to spot and calculate conservational problems in economic reporting as more stakeholders expressed concerns about this problem (Claudia-Maria \& Dragomir 2010; Nasih et al. 2019; El Idrissi et al. 2020). It causes the emergence of the consideration of corporate social responsibility information in yearly reports for various companies. The requirement for disclosure of social and environmental sustainability information is not mandatory; however, such action might increase companies' ability to accomplish sustainability objectives, by combining the outcomes of their economic, public and also environmental management activities into their reports (Çalişkan 2014). Not only could this information be disclosed as part of each company's published annual report, environmental and social information could also be disclosed separately in a standalone sustainability report. Furthermore, sustainability reports provide a different type of information to financial reports. Sustainability reports indicate the capability of a firm to create long-term value by considering its economic, social, and environmental performance (Kuzey \& Uyar 2017). There has been a growing awareness of the value of and propensity for issuing standalone sustainability reports, as reported by KPMG International. In 2013, 4,100 companies worldwide were surveyed by KPMG International which lead to 71 percent of those companies engaging with Corporate Social Responsibility (CSR) reporting. In spite of this, the existence of sustainability reports does not guarantee that the quality of the reported information will increase (Junior et al. 2014). Since the legal and regulatory necessities concerning sustainability reporting have not been established yet, unethical corporations may issue inaccurate reports about the activities that involves the community and environment in which exploiting the appearance of sustainability reporting value (Delmas \& Burbano 2011; Lyon \& Maxwell 2011) to convince the interpretation of stakeholders (Okoye 2009). Thus, Simnett et al. (2009) argued that assurance for sustainability reports will enhance the credibility and reliability of reports and help to build corporate reputation. The issue of integrity of information disclosed in reports leads to demands for more transparent reporting.

Due to the current growth in requests for assurance of sustainability reports from third-parties, Bepari \& Mollik (2016) found that the implementation of assurance was contemplated various default setting bodies on the scheme and unpaid for non-profit organisation; for example, the International Auditing and Assurance Standards Board (IAASB) has established a sustainability guarantee criterion and another not for profit-oriented organisation, Liability, has similarly established its own sustainability assurance requirement which is AA1000AS. Furthermore, as the known pioneer in standard makers for sustainability reporting, in 2000, GRI issued its initial set of sustainability report standards (GRI 1), and the newest reporting edition procedures, in 2013, GRI 4 was issued. Hence, how sustainability the implementation of assurance that accepts and supports the subject of liability for investors is a significant pragmatic matter (Bepari \& Mollik 2016). Since sustainability assurance is a new discipline, there is still an absence of assurors' freedom in the procedure of assurance (Ball et al. 2000), unpredictable possibilities, conditions used and assurance arrangement levels (Kamp 2002; Manetti \& Becatti 2009). To summarise, and in line with Bepari \& Mollik (2016), an assurance report arranged under the AA1000AS (2008), ISAE3000 (2008) and GRI involves information such as quality and requirement, assurance 


\section{ENTREPRENEURSHIP AND SUSTAINABILITY ISSUES}

ISSN 2345-0282 (online) http://jssidoi.org/jesi/ 2019 Volume 7 Number 2 (December) http://doi.org/10.9770/jesi.2019.7.2(..)

addressee, the assurance range, independence of the assurors, responsiveness, inclusivity, materiality, and assurance decisions from the perception of stakeholder liability.

When companies disclose their external assurance in a sustainability report, they hope to provide a well-defined figure to the investor, avoiding misapprehensions and misevaluations of their performance. Thus, a sign which is set by the management is reflected by the investor in terms of their valuation of the firm. To investigate this issue, we use a sample of listed firms from Indonesia and Malaysia during 2010-2016. All sectors are included in order to provide fair results in terms of a correlation between external assurance on sustainability report disclosure and firm value. The data related to the presence of external assurance on sustainability reports is derived from the sustainability reports of each company, which can be directly downloaded from company websites or from the Global Reporting Initiative database, if available. Meanwhile, data regarding each firm's financial information are derived from ORBIS. Our results indicate that firm value by proxy of Tobins'q is affected significantly by external assurance on sustainability report disclosure. This study adds new evidence to the literature on sustainability assurance in emerging countries. A prior study undertaken by Bepari \& Mollik (2016) only examined, in the Australian circumstances, whether the assurance implementations enhanced the accountability and transparency of organisational sustainability reporting. Our research is also different from Bepari \& Mollik (2016) in that we consider the effect on firm value, which they did not consider.

The structure of this paper is as follows: Part 2 is the literature review and hypothesis development; Part 3 gives a sample description and research variable; Part 4 includes the results and discussion; Part 5 is the conclusion, including limitations, and suggestions for this research.

\section{Theory and Hypothesis Development}

Legitimacy can be defined as a resource that is important for a company to function in the community. Suchman (1995) argued that the legitimacy is a functioning asset which is taken ambitiously by companies and engage it in reaching their objectives. According to the theory, organizations use a press release and various reporting to build a positive impression of the company and boost the reputation of the company and company legitimacy (Astutik et al. 2018) such as sustainability reporting and assurance as tools (Bebbington et al. 2008; Kolk 2010). Positive sustainability reporting improves the reputation of the company (Morimoto et al., 2005; Chehabeddine, Tvaronavičienè, 2020), and company sustainability reporting and assurance implementations are frequently used as sensible conceptions of legitimacy (Palazzo \& Scherer 2006). Cohen \& Simnett (2014) have argued that sustainability reporting and affiliated assurance implementations are both of the planned instruments used to further a company's desire to affect the community's perspective towards the legitimacy of the company. To modify the perspective of the community, organizations need to publish private information for the examination of external parties. The investor will use the information as a signal and matter for consideration when making an investment decision. As the information is given, the company management has more precise information concerning the state of the company, while investors need this kind of information when deciding to invest. Kuzey \& Uyar (2017) also support the signaling theory in terms of the value creation role in sustainability reporting. This finding has significant implications for firms. If they care about sustainability issues (i.e., environmental and social), they must announce this by issuing sustainability reports. Doing so will enhance their reputations while attracting individual and institutional investors. On the other hand, the current and upcoming conditions of a firm can be measured from the firm value, which also represents the collective assessment of investors; the growth of firm value can act as a positive indicator to investors and helps investors to make investment decisions. This reflection prevents the undervaluation of firms and, at the same time, contributes to the efficiency of the market.

Reporting of sustainability information is carried out willingly by companies (Sisaye, 2011), with the sole intention of disclosing information. The voluntary nature of disclosure indicates an inclination towards 


\section{ENTREPRENEURSHIP AND SUSTAINABILITY ISSUES}

ISSN 2345-0282 (online) http://jssidoi.org/jesi/ 2019 Volume 7 Number 2 (December) http://doi.org/10.9770/jesi.2019.7.2(..)

subjectivity from the management. Haigh \& Shapiro (2011) argued that subjectivity might increase as a reason for the complexity caused by calculations involved in sustainability reporting. The reliability of environmental data is arguable since reporting has done as optional. Hence, the subject regarding the audit of environmental and thirdparty assurance is necessary to be addressed (Zhou et al. 2013). Over the past decade, the market for assurance utility that offered for sustainability reports has expanded widely (Wong et al. 2016). A survey organized by KPMG AZSA (2014) about the listed company in the Nikkei 225, showed that the amount of company that collected third-party assurances in their environmental reports had raised yearly by $17 \%$ in 2010 to $25 \%$ in 2013 , according to the Sustainability Report 2014 in Japan. Moreover, the Japan Ministry of the Environment has publicized instructions regarding the technique of reliability enhancement of environmental reports (2014). The guidelines recommend the tools that can be used as the development of reliability in environmental reporting, which are self-evaluation, thorough internal audit, assurance of a third-party, and the opinion of a third party (Lee et al. 2017).

As stated by Adams \& Evans (2004), the assurance objective is to enhance the quality of information, which becomes a basis for decision making amongst stakeholders. In other words, the vital function of the demand for external assurance of sustainability reporting is the desire to enhance credibility. External assurance can play a significant role that has already been proven to affect the perception of increased credibility and reliability. Hodge et al. (2009) concluded that to make information on social and environmental issues more dependable, a statement of assurance should be involved. Still, it can be more effective when the assurance comes from reliable accounting firms, which are considered to be more accurate.

Besides reporting on sustainability report-related issues, the quality of the report also matters. Companies use sustainability reporting and external assurance as tools to enhance corporate legitimacy. When companies disclose their external assurance for a sustainability report, they hope to provide transparent information for the investor to avoid misjudgment and misevaluation of company performance. Thus, the signal which is given by the management is reflected by the investor in their valuation of the firm. At the same time, it also has a significant impact on companies in terms of building a positive corporate impression. It also increasing corporate prestige which causes the sales improvement, and boosted attractiveness to clients, creditors and officials (Green \& $\mathrm{Li}$ 2011; Kollman \& Prakash 2001; Zhou et al. 2013); this also increases firm value. Based on the above discussion, we propose the formal hypothesis as follows:

H1: Higher disclosure on external assurance of sustainability reporting results in higher firm value.

\section{Research Design and Methodology}

\subsection{Sample and Data Source}

The population in the research is taken from Indonesia-based companies listed on the Indonesian Stock Exchange (IDX) and Malaysian companies listed on Bursa Malaysia, as well as information provided at http://www.globalreporting.org. This research relies on secondary data acquired from sustainability reports to measure external assurance on sustainability report disclosure. All financial information required is obtained from the ORBIS database. All sectors are used in this research, including agriculture, aviation, conglomerates, food and beverage products, energy, forest and paper products, media, mining, and telecommunications. This research excludes the financial industry. This research also eliminates all companies that do not have the information needed. According to those criteria, the total sample for this research is 84 . Table 1 presents the observation distributions by year. 
ENTREPRENEURSHIP AND SUSTAINABILITY ISSUES

ISSN 2345-0282 (online) http://jssidoi.org/jesi/ 2019 Volume 7 Number 2 (December) http://doi.org/10.9770/jesi.2019.7.2(..)

Table 1. Sample Distribution

\begin{tabular}{|l|c|c|c|}
\hline YEAR & INDONESIA & MALAYSIA & TOTAL \\
\hline 2010 & 5 & 4 & 9 \\
\hline 2011 & 5 & 5 & 13 \\
\hline 2012 & 8 & 6 & 13 \\
\hline 2013 & 7 & 6 & 13 \\
\hline 2015 & 7 & 5 & 13 \\
\hline TOTAL & 8 & 6 & 13 \\
\hline
\end{tabular}

\subsection{Operational Variable Measurement}

External Assurance on Sustainability Report Disclosure: External assurance on sustainability report disclosure (DASR) is used as the independent variable in this research. This variable is measured using the contents of assurance statements proposed by Bepari \& Mollik (2016), which is calculated by counting the contents of the assurance statements disclosed by a company, 1 or 0 . If an item is disclosed, it will be valued 1 , and the total disclosed criteria would be summed. Table 2 provide the detail criteria of DASR.

\section{DASR $=\underline{\text { Total Disclosed }} \times 100 \%$}

14

Table 2. Information Content of External Assurance on Sustainability Report

\begin{tabular}{|l|l|}
\hline \multicolumn{1}{|c|}{ No } & \multicolumn{1}{|c|}{ Contents of the Assurance Statements } \\
\hline 1. & Intended users of the assurance statement \\
\hline 2. & The responsibility of the reporting organisation and of the assuror \\
\hline 3. & Assurance standard/s used \\
\hline 4. & Description of the scope, including the type of assurance provided \\
\hline 5. & Description of methodology \\
\hline 6 & Any limitations \\
\hline 7. & Reference to criteria used \\
\hline 8. & Statement of level of assurance \\
\hline 9. & Findings and conclusions concerning adherence to the AA1000AP \\
\hline 10. & Principles of Inclusivity, Materiality, and Responsiveness \\
\hline 11. & Findings and Conclusions \\
\hline 12. & Observations and/or recommendations \\
\hline 13. & Notes on independence and competence of the assuror \\
\hline 14. & Name of the assuror \\
\hline
\end{tabular}

Source: Bepari and Mollik (2016)

This research uses the firm value as the dependent variable. Previous research has contributed to this research in several ways. The dependent variable of firm value was taken from previous research (Cho et al. 2014; Kuzey \& Uyar 2017; Lee et al. 2017; Loh et al. 2017). As suggested by Bharadwaj et al. (1999) and Konar \& Cohen (2001), standard accounting measures of performance, such as return on assets, cannot evaluate the future profit potential of such practices. To overcome the limitations of these standard accounting measures, Jiang et al. (2007) stated that book value is a reasonable adjustment. Singh et al. (2017) considered Tobin's Q as their proxy for 
measuring firm value. Hence, the market value to book value (MV-BV) ratio refers to Tobin's Q, which is also used in this research. Market capitalization is measured by the number of outstanding shares times the market price per share.

\section{Tobins'q $=\underline{\text { Market Capitalization }} \times 100 \%$ Total Assets}

Following prior study (Kuzey \& Uyar 2017), this research uses firm size (FSIZE), profitability (ROA), leverage (LEV), and liquidity (LIQUIDITY) as the control variables. We also add a year fixed effect to ensure that our result is robust. We need to control the year as various regulations related sustainability emerges during past years, so there is a possibility that sustainability report issue from year to year is changing. The detail definition of the variables is provided in Table 3.

Table 3. Variabel Definition

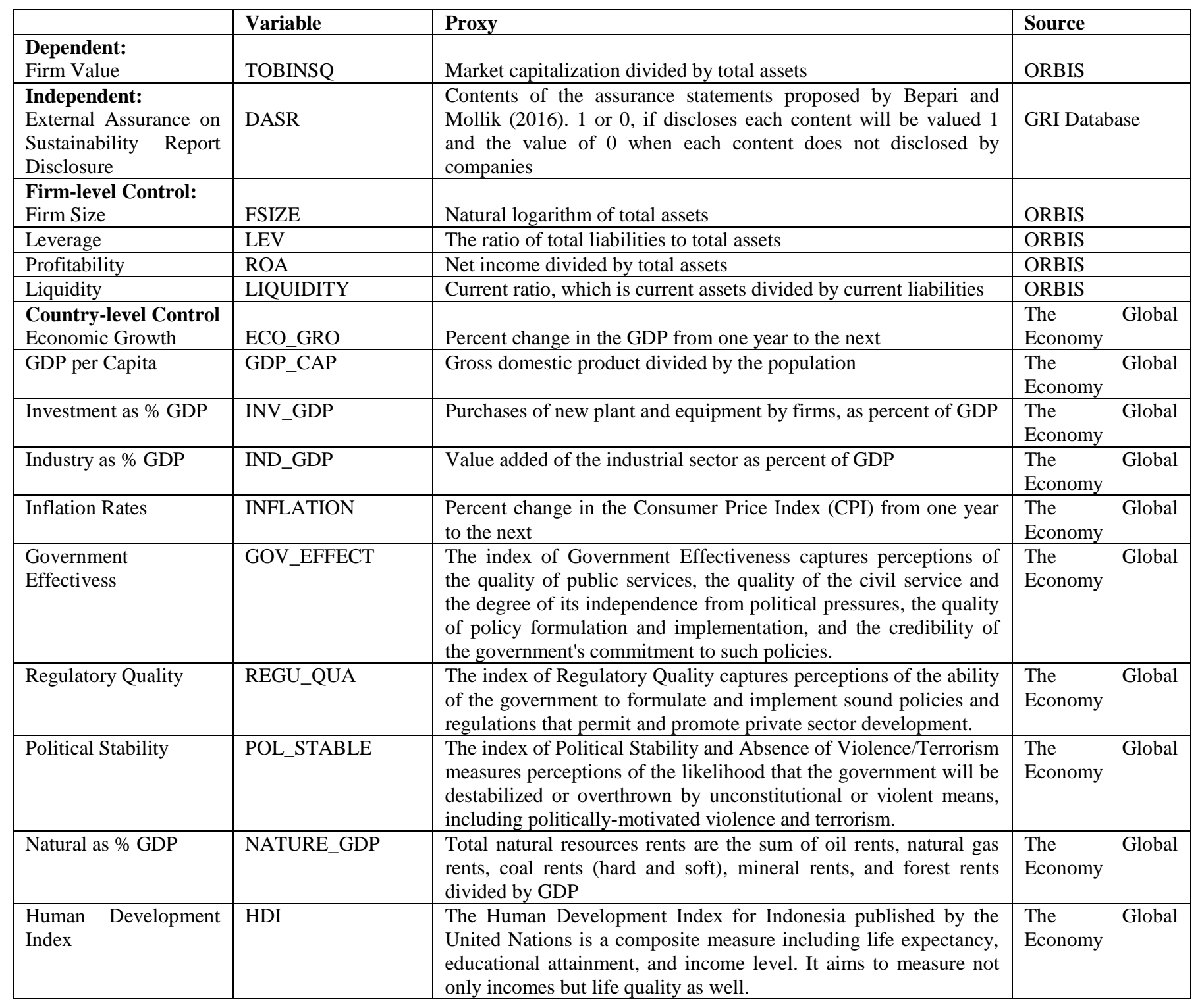


ENTREPRENEURSHIP AND SUSTAINABILITY ISSUES

ISSN 2345-0282 (online) http://jssidoi.org/jesi/ 2019 Volume 7 Number 2 (December) http://doi.org/10.9770/jesi.2019.7.2(..)

\section{Result and Discussion}

\subsection{Descriptive Statistics}

Table 4 provides descriptive statistics of all research variables in this study. An external assurance on sustainability report disclosure is measured using the contents of the assurance statements proposed by Bepari \& Mollik (2016), which is calculated by counting the contents of the assurance statements disclosed by the company, 1 or 0 . If an item is disclosed, it will be valued 1 , and the total disclosed criteria would be summed as stated in section 3. The variable name used is DASR. The highest DASR value is 1, and the lowest value is 0.571. Following the result, the descriptive statistic table is provided with other control variable mean, median, minimum, and maximum values. Also, it shows that, on average, companies in Indonesia have higher disclosure in sustainability reports compared to Malaysian firms.

Table 4. Statistic Descriptive

\begin{tabular}{|c|c|c|c|c|}
\hline Variable & Mean & Median & Minimum & Maximum \\
\hline TOBINSQ & 2.527 & 0.945 & 0.040 & 17.950 \\
\hline DASR & 0.788 & 0.7857143 & 0.571 & 1.000 \\
\hline DASR-INDONESIA & 0.897 & 0.9285714 & 0.643 & 1.000 \\
\hline DASR-MALAYSIA & 0.643 & 0.6428571 & 0.571 & 0.929 \\
\hline TASSET & 50400000 & 31300000 & 5191000 & 211100000 \\
\hline$L E V$ & 0.557 & 0.595 & 0.176 & 0.906 \\
\hline$R O A$ & 9.984 & 5.255 & -4.750 & 47.200 \\
\hline LIQUIDITY & 0.830 & 0.720 & 0.094 & 2.389 \\
\hline ECO_GRO & 5.439 & 5.290 & 4.220 & 7.420 \\
\hline GDP_CAP & 15790.265 & 10766.350 & 8433.500 & 25685.280 \\
\hline INV_GDP & 30.034 & 32.930 & 23.190 & 35.070 \\
\hline IND_GDP & 40.899 & 40.050 & 38.290 & 43.910 \\
\hline INFLATION & 4.017 & 3.500 & 1.600 & 6.400 \\
\hline GOV_EFFECT & 0.343 & 0.010 & -0.270 & 1.120 \\
\hline REGU_QUA & 0.168 & -0.110 & -0.420 & 0.840 \\
\hline POL_STABLE & -0.262 & -0.370 & -0.850 & 0.270 \\
\hline NATURE_GDP & 7.087 & 6.910 & 3.060 & 10.950 \\
\hline HDI & 0.726 & 0.691 & 0.661 & 0.799 \\
\hline
\end{tabular}

Note: This table displays the descriptive statistics for all variables in this study. The sample comprises 84 firms listed on the Indonesia Stock Exchange (IDX) and Bursa Malaysia for the years 2010-2016

\subsection{Pearson Correlation Test}

We also conduct the untabulated correlation matrix for all variables used in this study. An external assurance on sustainability report disclosure (DASR) has a positive correlation with Tobins'q (TOBINSQ), with a coefficient of 0.216 and significance at 5\%. This value means each disclosure will have the effect of increasing firm value by a proxy Tobins'q (TOBINSQ). The control variables, leverage, return on assets, and liquidity also has a positive correlation with Tobins'q (TOBINSQ) as well. Meanwhile, Firm Size (FSIZE) with Tobins'q (TOBINSQ) has a negative correlation and significance at $1 \%$ for $-(0.378)$; this means that companies with larger firm size (FSIZE) have a lower Tobins'q (TOBINSQ). 


\section{ENTREPRENEURSHIP AND SUSTAINABILITY ISSUES}

ISSN 2345-0282 (online) http://jssidoi.org/jesi/ 2019 Volume 7 Number 2 (December) http://doi.org/10.9770/jesi.2019.7.2(..)

\subsection{Ordinary Least Square Regression Test}

This research uses an Ordinary Least Square (OLS) regression model by using STATA 14.0 for regression analysis. In this research, the regression is done twice; the first regression is ordinary least square (OLS), and the second is ordinary least square (OLS) with robust using cluster approach. This method used to strengthen error standard in terms of the regression model, thus making the result relatively constant against any changes in the model. Also, this kind of cluster model is done to resolve the heteroscedasticity problem as our Breusch-Pagan test results show a p-value 0.0000 . This value means it has a heteroscedasticity problem in our OLS model. The linear regression model is as follows:

$$
\begin{aligned}
\text { TOBINS' }_{i, t} & =\beta_{0}+\beta_{1} \text { DASR }_{i, t}+\beta_{2} \text { FSIZE }_{i, t}+\beta_{3} L^{2} V_{i, t}+\beta_{4} \text { ROA }_{i, t}+\beta_{5} \text { LIQUIDITY }_{i, t}+\beta_{6} \text { YEAR }_{i, t}+ \\
& +\varepsilon_{i, t}
\end{aligned}
$$

\begin{tabular}{|c|c|c|c|}
\hline \multirow[t]{2}{*}{ Variable } & \multirow[t]{2}{*}{ Predicted sign } & \multicolumn{2}{|c|}{ TOBINSQ } \\
\hline & & $\begin{array}{l}(1) \\
\text { OLS }\end{array}$ & $\begin{array}{c}\text { (2) } \\
\text { Robust Regression }\end{array}$ \\
\hline DASR & + & $5.862^{* * *}(3.92)$ & $5.862^{* * *}(2.88)$ \\
\hline FSIZE & - & $-0.918^{* * * *}(-3.75)$ & $-0.918^{* * * *}(-3.51)$ \\
\hline$L E V$ & + & $3.191^{* *}(2.43)$ & $3.191^{* *}(2.51)$ \\
\hline ROA & + & $0.230^{* * *}(9.18)$ & $0.230^{* * *}(7.35)$ \\
\hline LIQUIDITY & + & $2.244^{* * *}(3.70)$ & $2.244^{* * *}(3.32)$ \\
\hline CONSTANT & & $19.675^{* * * *}(2.91)$ & $19.675^{* * *}(3.07)$ \\
\hline Year dummies & & Included & Included \\
\hline R-squared & & 0.898 & 0.898 \\
\hline $\mathrm{F}$ & & 0.000 & 0.000 \\
\hline$N$ & & 84 & 84 \\
\hline
\end{tabular}

Table 5. The result of regression table

Note: Regression models related external assurance on sustainability report disclosure which is $\boldsymbol{D A S R}$ to firm value which is TOBINSQ. The sample comprises 84 firms listed on the Indonesia Stock Exchange (IDX) and Bursa Malaysia from 2010 to 2016. Significance at $* 10 \%, * * 5 \%$ and $* * * 1 \%$

In line with the result shown in Table 5, the coefficient of DASR has a statistically positive significance of 5.862 at $1 \%$. The finding indicates that the better the disclosure of a firm in terms of external assurance on sustainability reporting, the higher value the disclosure will get in terms of firm value. Thus, the hypothesis is accepted. As shown in Table 6 column 2 using OLS robust, the finding of the research indicates that the FSIZE coefficient belongs to the condition which statistically negative significant at amount - $(0.918)$ at $1 \%$, the result shows that the bigger the size of the firm the lower the value gain, in terms of firm value. The research also found that the LEV coefficient belongs to the condition, which has a statistically positive significance of 3.191 at $5 \%$. In other words, an increase in the leverage will affect the firm value as well. Still using the results of Table 6, using OLS robust, the findings show that the ROA coefficient is in a condition that has a statistically positive significance of 0.230 at $1 \%$. The results show that a firm with a higher return on assets will have a higher value in terms of firm value. Lastly, using OLS robust, it was found that the LIQUIDITY coefficient is in a condition that has a statistically positive significance of 2.244 at $1 \%$. This result means that companies with a higher liquidity ratio have a higher value in terms of firm value.

\subsection{Additional Analysis}

We also employ various country-level control variables to ensure our result is robust. As shown in table 6, we confirmed that even after we add some country-level control variables, the result is consistent. It still confirmed that our hypothesis is accepted, in which higher disclosure on the external assurance of sustainability reporting results in higher firm value. It can be said that regardless of the country, which in this research context are 
ENTREPRENEURSHIP AND SUSTAINABILITY ISSUES

ISSN 2345-0282 (online) http://jssidoi.org/jesi/ 2019 Volume 7 Number 2 (December) http://doi.org/10.9770/jesi.2019.7.2(..)

Indonesia and Malaysia, our research result is consistent. Similar to our initial regression model, we also employ a cluster approach as Breusch-Pagan tests show a p-value of 0.000 .

Table 6. Regression result using country-level variables

\begin{tabular}{|c|c|c|c|}
\hline \multirow[t]{2}{*}{ Variable } & \multirow[t]{2}{*}{ Predicted Sign } & \multicolumn{2}{|c|}{ TOBINSQ } \\
\hline & & $(1)$ & $(2)$ \\
\hline DASR & + & $6.587^{* * *}(2.63)$ & $6.587^{* * *}(2.31)$ \\
\hline LEV & + & $3.178^{* *}(2.29)$ & $3.178^{* *}(2.26)$ \\
\hline ROA & + & $0.234^{* * * *}(8.93)$ & $0.234^{* * * *}(7.37)$ \\
\hline LIQUIDITY & + & $2.206^{* * *}(3.56)$ & $2.206^{* * * *}(3.19)$ \\
\hline INV_GDP & + & $4.756(0.54)$ & $4.756(0.62)$ \\
\hline IND_GDP & + & $-3.095(-0.65)$ & $-3.095(-0.77)$ \\
\hline INFLATION & + & $3.169(0.40)$ & $3.169(0.45)$ \\
\hline GOV_EFFECT & + & $31.071(0.36)$ & $31.071(0.39)$ \\
\hline REGU_QUA & + & $-103.963(-0.47)$ & $-103.963(-0.53)$ \\
\hline Year dummies & & Included & Included \\
\hline Country dummies & & Included & Included \\
\hline R-Squarred & & 0.907 & 0.907 \\
\hline $\mathrm{F}$ & & 0.000 & 0.000 \\
\hline$N$ & & 84 & 84 \\
\hline
\end{tabular}

\subsection{Discussion}

The hypothesis in this research stated that the higher the disclosure of external assurance on sustainability reporting, the more likely a firm is to have higher firm value. Based on the results of various techniques of analysis carried out, using Pearson correlations and regression results, external assurance on sustainability report disclosure (DASR) and firm value (TOBINSQ) have a positive and significant relationship. Hence, the hypothesis is accepted. The finding of the research shows that such disclosure is a substantial factor for firm value by the proxy of Tobins'q. This result means that higher disclosure of external assurance of sustainability reporting will lead to higher firm value. The results of this study are consistent with research conducted by Clarkson et al. (2013), where the disclosure of voluntary environmental information provided valuation relevant information that could increase the value of the firm. Clarkson et al. (2013) declared that the disclosure of voluntary environmental information is a balanced outcome from the process of selection that improves the calculation of financial performance. However, "to serve this role, once again, they have to be viewed as credible and convey incremental information," that is, to serve concerning its role, the disclosure must be credible in which information is "assured by external professional verification" (Beets \& Souther 1999). When companies disclose their external assurance of sustainability reporting, they hope to give an exact figure to the investor, to avoid their performance being misconstrued and miscalculated. Thus, the indication provided by the management is revealed in the assessment of the firm by the investor. At the same time, there is a significant impact for companies in terms of creating a positive corporate image and enhancing corporate prestige which causes the sales improvement, and boosted attractiveness to clients, creditors and officials (Green \& Li 2011; Kollman \& Prakash 2001; Zhou et al. 2013). 


\section{ENTREPRENEURSHIP AND SUSTAINABILITY ISSUES}

ISSN 2345-0282 (online) http://jssidoi.org/jesi/ 2019 Volume 7 Number 2 (December) http://doi.org/10.9770/jesi.2019.7.2(..)

Image and an excellent reputation for the company's performance are some of the considerations of investors to allow them to make investment decisions. Therefore, investors tend to invest in companies that have a good reputation, since nowadays, stakeholders occasionally prefer to choose based on the company's future environmental performance. It is concluded that external assurance of sustainability report disclosure could give a signal to the stock market regarding environmental strategy and commitment to the protection of the environment, which results in additional investment, hence increasing firm value. According to the above explanation, firm value is positively affected by the external assurance of sustainability report disclosure.

\section{Conclusion}

We demonstrated that variations in sustainability report disclosure with external assurance influence investor perception, which affects firm value. Using two major countries in ASEAN as our sample, this research investigated the relationship between external assurance of sustainability report disclosures and firm value in Indonesian and Malaysian firms for the 2010-2016 period. The purpose of external assurance is to decrease information asymmetry in voluntary disclosure reports. We found that firms in Indonesia present a higher level of disclosure relative to Malaysian firms. We also found that firms with an external assurance of their sustainability report disclosure are valued higher by investors.

We encounter limitations during the conduct of this research. We are aware that this sample research is considered small as only a few firms that publish a sustainability report. Even particular firms publish sustainability reports, but those firms are not guaranteed those following GRI guidelines, which, as a result, we cannot add those firms as our sample to minimize bias in our external assurance on sustainability report disclosure variable. This research's implication is both academic and practical. In academics, this research can be used as fruitful materials for future research that focuses on external assurance on sustainability report disclosure as this research provides new evidence about sustainability assurance on two emerging countries. As for practitioners, it can serve as discussion material in terms of corporate policy planning and implementation in the context of sustainability reports.

\section{References}

Adams, C. A., \& Evans, R., 2004. Accountability, completeness, credibility and the audit expectations gap. Journal of corporate citizenship, 14(Summer), 97-115. https://doi.org/10.9774/GLEAF.4700.2004.su.00010

Astutik, D., Harymawan, I., \& Nasih, M. 2018. The effectiveness of social media and press release transparency to detect indications of financial fraud. Journal of Applied Economic Sciences, 13, 1507-1518. Retrieved from

https://www.researchgate.net/publication/331161843_The_effectiveness_of_social_media_and_press_release_transparency_to_detect_indi cations of financial fraud

Ball, A., Owen, D. L., \& Gray, R. 2000. External transparency or internal capture? The role of third party statements in adding value to corporate environmental reports. Business Strategy and the Environment, 9(1), 1-23. https://doi.org/10.1002/(SICI)1099$\underline{0836(200001 / 02) 9: 13.0 . \mathrm{CO} ; 2-\mathrm{H}}$

Bebbington, J., Larrinaga, C., \& Moneva, J. M. 2008. Corporate social reporting and reputation risk management. Accounting, Auditing \& Accountability Journal, 21(3), 337-361. https://doi.org/10.1108/09513570810863932

Beets, S. D., \& Souther, C. C., 1999. Corporate environmental reports: the need for standards and an environmental assurance service. Accounting Horizons, 13(2), 129-145. https://doi.org/10.2308/acch.1999.13.2.129 


\section{ENTREPRENEURSHIP AND SUSTAINABILITY ISSUES}

ISSN 2345-0282 (online) http://jssidoi.org/jesi/ 2019 Volume 7 Number 2 (December) http://doi.org/10.9770/jesi.2019.7.2(..)

Bepari, M. K., \& Mollik, A. T., 2016. Stakeholders' interest in sustainability assurance process: An examination of assurance statements reported by Australian companies. Managerial Auditing Journal, 31(6/7), 655-687. https://doi.org/10.1108/MAJ-06-2015-1208

Bharadwaj, A. S., Bharadwaj, S. G., \& Konsynski, B. R. 1999. Information technology effects on firm performance as measured by Tobin's q. Management science, 45(7), 1008-1024. https://doi.org/10.1287/mnsc.45.7.1008

Chehabeddine, M., Tvaronavičienè, M. 2020. Securing regional development. Insights into Regional Development, 2(1), 430-442. http://doi.org/10.9770/IRD.2020.2.1(3)

Clarkson, P. M., Fang, X., Li, Y., \& Richardson, G. 2013. The relevance of environmental disclosures: are such disclosures incrementally informative? Journal of Accounting and Public Policy, 32(5), 410-431. https://doi.org/10.1016/j.jaccpubpol.2013.06.008

Claudia-Maria, B., \& Dragomir, V. D. 2010. The sustainability policy of five leading European retailers. Accounting and Management Information Systems, 9(2), 268. Retrieved from https://eds.b.ebscohost.com/eds/detail/detail?vid=0\&sid=8e074f80-c69b-4e8e-a25e1 cbff $235 \mathrm{e} 3 \mathrm{a} 3 \% 40 \mathrm{pdc}-\mathrm{v}-$ sessmgr01\&bdata=JkF1dGhUeXB1PWNvb2tpZSxpcCx1cmwsdWlkLHNoaWImc210ZT11ZHMtbG12ZQ\%3d\%3d\#db=buh\&AN=6050252 $\underline{5}$

Cohen, J. R., \& Simnett, R. 2014. CSR and assurance services: A research agenda. Auditing: A Journal of Practice \& Theory, 34(1), 59-74. https://doi.org/10.2308/ajpt-50876

Crifo, P., Diaye, M.-A. \& Pekovic, S. 2016. CSR related management practices and firm performance: An empirical analysis of the quantity-quality trade-off on French data. International Journal of Production Economics, 171, 405-416. https://doi.org/10.1016/j.ijpe.2014.12.019

Delmas, M. A., \& Burbano, V. C. 2011. The drivers of greenwashing. California Management Review, 54(1), 64-87. https://doi.org/10.1525/cmr.2011.54.1.64

El Idrissi, N. E. A., Ilham Zerrouk, I., Naoual Zirari, N., Salvatore Monni, S. 2020. Comparative study between two innovative clusters in Morocco and Italy. Insights into Regional Development, 2(1), 400-417. http://doi.org/10.9770/IRD.2020.2.1(1)

Gardiner, L., Rubbens, C. \& Bonfiglioli, E., 2003. Research: Big business, big responsibilities. Corporate Governance, 3(3), 67-77. https://doi.org/10.1108/14720700310483451

Green, W., \& Li, Q., 2011. Evidence of an expectation gap for greenhouse gas emissions assurance. Accounting, Auditing \& Accountability Journal, 25(1), 146-173. https://doi.org/10.1108/09513571211191789

H. Cho, C., Michelon, G., M. Patten, D., \& W. Roberts, R. 2014. CSR report assurance in the USA: an empirical investigation of determinants and effects. Sustainability Accounting, Management and Policy Journal, 5(2), 130-148. https://doi.org/10.1108/SAMPJ-01$\underline{2014-0003}$

Haigh, M., \& Shapiro, M. A. 2011. Carbon reporting: does it matter? Accounting, Auditing \& Accountability Journal, 25(1), 105-125. https://doi.org/10.1108/09513571211191761

Hodge, K., Subramaniam, N., \& Stewart, J. 2009. Assurance of sustainability reports: Impact on report users' confidence and perceptions of information credibility. Australian accounting review, 19(3), 178-194. https://doi.org/10.1111/j.1835-2561.2009.00056.x

Jiang, B., Belohlav, J. A., \& Young, S. T. 2007. Outsourcing impact on manufacturing firms' value: Evidence from Japan. Journal of Operations Management, 25(4), 885-900. https://doi.org/10.1016/j.jom.2006.12.002

Jones, M. J., \& Solomon, J. F. 2010. Social and environmental report assurance: Some interview evidence. Accounting Forum, 34(1), 2031. https://doi.org/10.1016/j.accfor.2009.11.002

Junior, R. M., Best, P. J., \& Cotter, J. 2014. Sustainability reporting and assurance: A historical analysis on a world-wide phenomenon. Journal of Business Ethics, 120(1), 1-11. https://doi.org/10.1007/s10551-013-1637-y

Kamp, A. E. M. 2002. Towards a Framework for Auditing Environmental Reports. Tilburg University, Open Access Publications from Tilburg University. Retrieved from https://pure.uvt.nl/ws/portalfiles/portal/485107/kamp-roelands.pdf 


\section{ENTREPRENEURSHIP AND SUSTAINABILITY ISSUES}

ISSN 2345-0282 (online) http://jssidoi.org/jesi/ 2019 Volume 7 Number 2 (December) http://doi.org/10.9770/jesi.2019.7.2(..)

Kolk, A. 2010. Trajectories of sustainability reporting by MNCs. Journal of World Business, 45(4), 367-374. https://doi.org/10.1016/j.jwb.2009.08.001

Kollman, K., \& Prakash, A. 2001. Green by choice? Cross-national variations in firms' responses to EMS-based environmental regimes. World Politics, 53(3), 399-430. https://doi.org/10.1353/wp.2001.0010

Konar, S., \& Cohen, M. A. 2001. Does the market value environmental performance? Review of economics and statistics, 83(2), $281-289$. https://doi.org/10.1162/00346530151143815

Kuzey, C., \& Uyar, A. 2017. Determinants of sustainability reporting and its impact on firm value: Evidence from the emerging market of Turkey. Journal of Cleaner Production, 143, 27-39. https://doi.org/10.1016/j.jclepro.2016.12.153

Lee, K. H., Park, B. J., Song, H., \& Yook, K. H. 2017. The value relevance of environmental audits: evidence from Japan. Business strategy and the environment, 26(5), 609-625. https://doi.org/10.1002/bse.1940

Loh, L., Thomas, T., \& Wang, Y. 2017. Sustainability Reporting and Firm Value: Evidence from Singapore-Listed Companies. Sustainability, 9(11), 2112. https://doi.org/10.3390/su9112112

Lyon, T. P., \& Maxwell, J. W. 2011. Greenwash: Corporate environmental disclosure under threat of audit. Journal of Economics \& Management Strategy, 20(1), 3-41. https://doi.org/10.1111/j.1530-9134.2010.00282.x

Manetti, G., \& Becatti, L. 2009. Assurance services for sustainability reports: Standards and empirical evidence. Journal of Business Ethics, 87(1), 289-298. https://doi.org/10.1007/s10551-008-9809-X

Morimoto, R., Ash, J., \& Hope, C. 2005. Corporate social responsibility audit: From theory to practice. Journal of Business Ethics, 62(4), 315-325. https://doi.org/10.1007/s10551-005-0274-5

Nasih, M., Harymawan, I., Paramitasari, Y. I., \& Handayani, A. 2019. Carbon emissions, firm size, and corporate governance structure: Evidence from the mining and agricultural industries in Indonesia. Sustainability (Switzerland), 11(9). https://doi.org/10.3390/su11092483

O’Dwyer, B., Owen, D., \& Unerman, J. 2011. Seeking legitimacy for new assurance forms: The case of assurance on sustainability reporting. Accounting, Organizations and Society, 36(1), 31-52. https://doi.org/10.1016/j.aos.2011.01.002

Okoye, A. 2009. Theorising corporate social responsibility as an essentially contested concept: is a definition necessary? Journal of Business Ethics, 89(4), 613-627. https://doi.org/10.1007/s10551-008-0021-9

Özsözgün Çalişkan, A. 2014. How accounting and accountants may contribute in sustainability? Social Responsibility Journal, 10(2), 246267. https://doi.org/10.1108/SRJ-04-2012-0049

Palazzo, G., \& Scherer, A. G. 2006. Corporate legitimacy as deliberation: A communicative framework. Journal of Business Ethics, 66(1), 71-88. https://doi.org/10.1007/s10551-006-9044-2

Sawani, Y., Mohamed Zain, M., \& Darus, F. 2010. Preliminary insights on sustainability reporting and assurance practices in Malaysia. Social Responsibility Journal, 6(4), 627-645. https://doi.org/10.1108/17471111011083482

Simnett, R., Vanstraelen, A., \& Chua, W. F. 2009. Assurance on sustainability reports: An international comparison. The accounting review, 84(3), 937-967. https://doi.org/10.2308/accr.2009.84.3.937

Singh, P. J., Sethuraman, K., \& Lam, J. Y. 2017. Impact of corporate social responsibility dimensions on firm value: Some evidence from Hong Kong and China. Sustainability, 9(9), 1532. https://doi.org/10.3390/su9091532

Sisaye, S. 2011. Ecological systems approaches to sustainability and organizational development: Emerging trends in environmental and social accounting reporting systems. Leadership \& Organization Development Journal, 32(4), 379-398. https://doi.org/10.1108/01437731111134652

Suchman, M. C. 1995. Managing legitimacy: Strategic and institutional approaches. Academy of management review, 20(3), 571-610. https://doi.org/10.2307/258788

Wong, J., Wong, N., Li, W. Y., \& Chen, L. 2016. Sustainability assurance: an emerging market for the accounting profession. Pacific Accounting Review, 28(3), 238-259. https://doi.org/10.1108/PAR-11-2014-0038 


\section{ENTREPRENEURSHIP AND SUSTAINABILITY ISSUES}

ISSN 2345-0282 (online) http://jssidoi.org/jesi/ 2019 Volume 7 Number 2 (December) http://doi.org/10.9770/jesi.2019.7.2(..)

Zhou, S., Simnett, R., \& Green, W. 2013. The effect of legal environment and corporate governance on the decision to assure and assurance provider choice: Evidence from the GHG assurance market. UNSW Australian School of Business Research Paper. A, 5. Retrieved https://www.researchgate.net/publication/276320476_The_effect_of_legal_environment_and_corporate_governance_on_the_decision_to_a ssure_and_assurance_provider_choice_Evidence_from_the_GHG_assurance_market

Zhu, Q., Liu, J. \& Lai, K.-H. 2016. Corporate social responsibility practices and performance improvement among Chinese national stateowned enterprises. International Journal of Production Economics, 171, 417-426. https://doi.org/10.1016/j.ijpe.2015.08.005

\section{Aknowledgements}

This research has received funding from the Tahir World Class Professorship

Iman HARYMAWAN is a Assistant Professor in the Department of Accounting, Faculty of Economics and Business, Universitas Airlangga, Indonesia. He obtained his PhD degree (2016) in accounting from City University of Hong Kong in Hong Kong, MBA degree (2009) from National Cheng Kung University in Taiwan, and his B.A. degree (2006) in accounting from Universitas Airlangga in Indonesia. His current research focuses include: corporate governance issues, the accounting impact of political and military connections in business, and financial reporting quality. He currently teaches financial reporting analysis, managerial accounting, and advanced accounting. Research interest: board connection; corporate governance, management accounting

ORCID ID: orcid.org/0000-0001-7621-6252

Mohammad NASIH is the Professor of Department of Accounting, Faculty of Economics and Business, Universitas Airlangga, Indonesia. Currently he is rector of Universitas Airlangga for period 2015 - 2020. He obtained his Doctoral degree (2005) in accounting from Universitas Airlangga in Indonesia, Master degree (1997) in Industry Technology from Institut Teknologi Bandung in indonesia, Bachelor degree (1991) in accounting from Universitas Airlangga in Indonesia. Research interest: islamic accounting; financial accounting

ORCID ID: orcid.org/0000-0002-7945-7593

Atila SALSABILLA is an accounting graduate with background of working in a professional setting as Big-4 auditor, experienced in working as a team and individually under tight schedule with multiple clients. She currently works as internal auditor in PT Kliring Penjaminan Efek Indonesia, one of the Self-Regulatory Organization (SRO) under the supervision of the Indonesia Financial Services Authority (IFSA) that given the authority to make and implement regulations related to its function as LKP in Indonesian capital market. Research interest: corporate social responsibility; auditing

ORCID ID: orcid.org/0000-0003-4641-376X

Fajar Kristanto Gautama PUTRA is master student in accounting from Universitas Airlangga in Indonesia. He obtained his bachelor degree (2018) in accounting from Universitas Airlangga. He currently works as reseach assistant in Center of Politic, Economic, and Business Research (CPEBR), a researcher grup that operates under Faculty of Economics and Business, Universitas Airlangga, Indonesia. Research interest: human resources disclosure; sustainability reporting

ORCID ID: orcid.org/0000-0003-1213-0593

Copyright (C) 2020 by author(s) and VsI Entrepreneurship and Sustainability Center

This work is licensed under the Creative Commons Attribution International License (CC BY).

http://creativecommons.org/licenses/by/4.0/

(c) (i) Open Access 